\title{
Long-term effects of potassium fertilization on yields and fertility status of calcareous soils of south-west France
}

\author{
C. Jouany *, B. Colomb, M. Bosc \\ I.N.R.A., station d'Agronomie, B.P. 27, Auzeville, 31326 Castanet-Tolosan, France
}

Accepted 6 May 1996

\begin{abstract}
A long-term field experiment was conducted near Toulouse (south-west France) to verify to what extent increasing fertilizer dressings would increase yields on calcareous soils in a cereals-oilseeds-legumes rotation. Over a 25 -year period, withholding $K$ significantly depressed yield once; $K$ inputs affected the total amount of $K$ absorbed at flowering, without subsequent effects on yields.

Exchangeable $\mathrm{K}$ content on non-fertilized plots declined slightly over the experimental period, but without reaching levels expected from nutrient balance estimates. Annual applications of $\mathrm{K}$ equal to average offtake in grain were adequate to maintain available soil $\mathrm{K}$ content at its initial value.

Potassium release kinetics for the exchangeable fraction, evaluated from Ca-resin extraction, clearly discriminated between fertilized and non-fertilized treatments. Both soils exhibited similar patterns for diffusion-controlled $\mathrm{K}$ release. These results highlight the role of $\mathrm{K}$ reserves readily available in illite-rich calcareous soils and demonstrate the importance of cultural residues in $\mathrm{K}$ fertility management.
\end{abstract}

Keywords: Long-term experimentation; $\mathrm{K}$ fertilization; $\mathrm{K}$ availability; $\mathrm{Ca}$ resin; Calcareous soil; Cereals; Oilseed plants; Legumes

\section{Introduction}

The objectives of mineral $P$ and $K$ fertilization practices for the major crops in Europe in the 1970 s werc until recently (1) to fully mect crop demand and (2) to increase soil reserves (Bosc, 1988).

Recent increases in fertilizer prices and changes in EC price support policies for these crops have led farmers to reduce or even withhold fertilizer

* Corresponding author. inputs. The question is asked about the sustainability of such practices, when establishing new cultural systems characterized by de-intensification and diversified production.

Reports on field experiments conducted on calcareous soils show little or no response to $\mathrm{K}$ applications and no depressive effect on yields when withholding K (Havlin et al., 1984; Withers et al., 1994). Also, several studies demonstrate that non-exchangeable $\mathrm{K}$ from reserves makes an important contribution to plant $K$ supply (Badraoui et al., 1992; Mengel and Uhlenbecker, 1993). Such results were obtained on soils with 
K-rich fractions: illite (Havlin et al., 1985; Badraoui et al., 1992) or fine sands (Parker et al., 1989) which are able to supply crops with large amounts of $\mathrm{K}$, which is difficult to assess from normal soil analysis. The estimation of $K$ available to crops as well as most of the $\mathrm{K}$ fertilizer recommendations are based on soil analyses and do not consider $\mathrm{K}$ release from the non-exchangeable fraction (Parker et al., 1989). It is also important to fully understand processes involved in nonexchangeable $\mathrm{K}$ release in order to formulate models that simulate mineral uptake by the major crops (Fardeau et al., 1992).

Sequential extraction of $\mathrm{K}$ with a $\mathrm{Ca}$-exchange resin is one of the few methods which are suitable to assess the kinetics of non-exchangeable $\mathrm{K}$ release, in that it proceeds without altering the mineral matrix. The experimental procedure simulates release processes, as they are in close proximity to active roots (Talibudeen et al., 1978; Goulding, 1984; Havlin et al., 1985). When extraction is carried on for several weeks, it becomes possible to assess the soil's potential for long-term K supply (Goulding and Loveland, 1986).

The present work reports on long-term field experiments started in 1968, which tested four different annual fertilizer rates. The specific objectives of the study were: (1) to examine the response of eight intensively managed crops to indigenous and applied $K ;(2)$ to follow the evolution of soil $\mathrm{K}$ status over the experimental period; and (3) to investigate $\mathrm{K}$ release kinetics from $\mathrm{Ca}$-resin extraction in a highly depleted soil and a heavily fertilized one.

\section{Materials and methods}

A long-term fertilization experiment was established in 1968 at the Agronomy Station of I.N.R.A., located at Auzeville, $15 \mathrm{~km}$ south-east of Toulouse (France). It compared four annual treatments arranged in four replicates (blocks): $\mathrm{KO}, \mathrm{K} 1, \mathrm{~K} 2$ and $\mathrm{K} 4$, corresponding to $0,33,66$, and $133 \mathrm{~kg} \mathrm{ha}^{-1} \mathrm{~K}$. The plot area was $300 \mathrm{~m}^{2}$ $(6 \times 50 \mathrm{~m})$. Potassium fertilizer was applied as $\mathrm{KCl}$ or $\mathrm{K}_{2} \mathrm{SO}_{4}$; each plot received $35 \mathrm{~kg} \mathrm{ha}^{-1} \mathrm{P}$ as superphosphate; potassium and phosphorus fertilizers were spread by hand before ploughing. Nitrogen fertilization was split into two applications: before sowing, and at the beginning of the period of most rapid growth. The average $\mathrm{N}$ input was $180 \mathrm{~kg} \mathrm{ha}^{-1}$ for maize, $150 \mathrm{~kg} \mathrm{ha}^{-1}$ for sorghum, $110 \mathrm{~kg} \mathrm{ha}^{-1}$ for wheat, $100 \mathrm{~kg} \mathrm{ha}^{-1}$ for rape and $80 \mathrm{~kg} \mathrm{ha}^{-1}$ for sunflower. Legumes were grown without $\mathbf{N}$ fertilization. Only maize was irrigated, with an ample supply of water. Harvest was performed with a combine adapted to the field dimensions, on the central rows of each plot. Grain was taken off; straw and above-ground parts were returned to the soil and incorporated with tillage. Yield was measured for each harvest except for the 1972 sunflower, when a hail-storm damaged the field after flowering. Occasionally, measurcments of plant total $\mathrm{K}$ content were performed at well-defined growth stages or at harvest. Analysis for $\mathrm{K}$ content was carried out after wet-mineralization of the sample using flame emission spectrophotometry. Cumulative nutrient balance for $\mathrm{K}$ (inputs minus outputs) was calculated from yields and grain contents. Exchangeable $\mathrm{K}$ balance was calculated as the difference between final and initial exchangeable $\mathrm{K}$ content per hectare (on the basis of $4500 \mathrm{t}$ soil ha ${ }^{-1}$, assuming an homogeneous apparent bulk density of $1.5 \mathrm{~g} \mathrm{~cm}^{-3}$ for the $0-30 \mathrm{~cm}$ surface horizon). Treatment effects on grain yield and $\mathrm{K}$ contents were calculated by analysis of variance.

The experimental field was located in a valley, representative of large scale farming areas of southwest France (Robert et al., 1988). The soil was developed on molasse sediments, a tertiary deposit coming from the Pyrenees. Annual mean precipitation is $700 \mathrm{~mm}$, unevenly distributed over the year with high water deficit in summer; the annual average temperature is $13^{\circ} \mathrm{C}$.

Fifteen discrete samples from the $0-30 \mathrm{~cm}$ soil horizon were collected at the beginning of the experiment. Fertility measurements were made regularly on the different plots; the soil was collected after harvest and incorporation of plant straw and above-ground parts, when the surface horizon had been moistened to field capacity. The samples were air-dried, then ground and sieved to $2 \mathrm{~mm}$ before 
processing. Exchangeable $\mathrm{K}$ was estimated from $\mathrm{NH}_{4}$-acetate extraction (Metson, 1956); total $\mathrm{K}$ was measured after dissolution with HF (Jackson, 1969); potassium extracted with NaTPB (sodium tetraphenyl boron) was obtained according to the method of Reed and Scott (1962).

The soil capacity for $\mathrm{K}$ release was tested through sequential extraction with a Ca-resin. The methodology developed by Talibudeen et al. (1978) was applied to the soil of the $\mathrm{K} 0$ and $\mathrm{K} 4$ plots from block III. Experimentally, $2 \mathrm{~g}$ of calciumsaturated Amberlite IR-120 resin (Serva, 20-50 mesh, $2.3 \mathrm{meq}^{-1}$ ) was placed in a centrifuge tube with $10 \mathrm{ml}$ of deionized water and $1 \mathrm{~g}$ of soil was added. All extractions were run in duplicate, a check sample without soil being prepared for each sample. The tubes were rotated on a roller-mixer for periods of time varying between $15 \mathrm{~min}$ and $471 \mathrm{~h}$, the procedure being run for a total reaction time of $6700 \mathrm{~h}$ ( 280 days). Following each contact period, the soil was separated from the resin by wet sieving at $0.25 \mathrm{~mm}$. The soil suspension was centrifuged and the supernatant recovered for $K$ analysis. The slurry was re-suspended with $10 \mathrm{ml}$ of deionized water and a new lot of resin was added. After incubation with the soil the resin was eluted with $200 \mathrm{ml}$ of $0.05 \mathrm{M}$ $\mathrm{CaCl}_{2}$. Potassium content in the supernatant and eluate was obtained by flame emission spectrophotometry. The total amount released from the soil is equal to the sum of the $\mathrm{K}$ absorbed on the resin and the $\mathrm{K}$ in the supernatant, corrected for the control sample. The solution $\mathrm{K}$ concentration never exceeded $0.2 \mathrm{mM}$, and the resin $\mathrm{K}$ saturation $0.2 \%$. The ratio resin C.E.C./soil C.E.C. was equal to 25 .

The cumulative $\mathrm{K}$ released was plotted as a function of the square rool of the cumulative reaction time (Fig. 1). Goulding (1984) demonstrated that separation of $\mathrm{K}$ release curves into two or more straight lines always gives a better fit to experimental data than a smooth curve. The amounts of $\mathrm{K}$ released $\left(\mathrm{M}_{1}, \mathrm{M}_{2}, \mathrm{M}_{3}\right)$ were calculated by extrapolating each linear segment (respectively, $1,2,3$ ) back to $t^{1 / 2}=0$ and taking the difference between the intercepts. Rates of release $\left(R_{1}, R_{2}, R_{3}\right)$ were calculated as the slope of each segment.

\section{Results}

\subsection{Grain yield response to applied potassium}

Over the 25 years of experimentation mean grain yields measured for the eight different species were representative of regional potential values.

The average yield increase for fertilized plots in comparison to the control was small (less than $1 \mathrm{t} \mathrm{ha}^{-1}$ ), except in 2 years. In 1979 , average yield for wheat was significantly greater $(P<0.05)$ from the $\mathrm{K} 4$ treatment than from the non-treated. Irrigated catch-maize grown in 1987 after winter pea and without extra fertilizer gave a very significant $(P<0.01)$ mean yield response to $\mathrm{K}$ fertilization.

Potassium contents measured on grain at harvest were similar to those usually reported; no statistically significant increase in $\mathrm{K}$ content due to fertilizer application was observed. Significant differences between treatments $(P<0.05)$ were noticeable when $\mathrm{K}$ content was determined on the whole plant at maximum adsorption stages. In 1973, K content of soyabean plants (pod filling), was significantly increased in the $\mathrm{K} 4$ treatment. A significant response to $\mathrm{K}$ fertilization was obtained for the $\mathrm{K}$ content of wheat plants (at ear emergence) in 1990.

\subsection{Changes with time in soil potassium status}

Table 1 shows the physical and chemical properties of the soil measured at the beginning of the experiment. The soil contained large amounts of $\mathrm{K}$ throughout the profile. Exchangeable $\mathrm{K}$ decreased with depth, most of it being located in the upper horizons, $0-30$ and $30-45 \mathrm{~cm}$. This soil had a high level of exchangeable $K$. The clay fraction $(<2 \mu \mathrm{m})$ contained mainly illite, smectite and interstratified illite-smectite minerals; the smectite has a high tetrahedral charge and belongs to the beidellite group (Robert et al., 1988).

Changes in exchangeable $\mathrm{K}$ between the beginning of the experiment and 1988 are shown in Fig. 2. Over this period, the soil $\mathrm{K}$ content for the non-fertilized plots slightly decreased in comparison with its initial value $\left(26 \mathrm{mg} \mathrm{K} \mathrm{kg}{ }^{-1}\right.$ soil $)$. Plots receiving minimum $\mathrm{K}$ fertilization (K1) showed a 


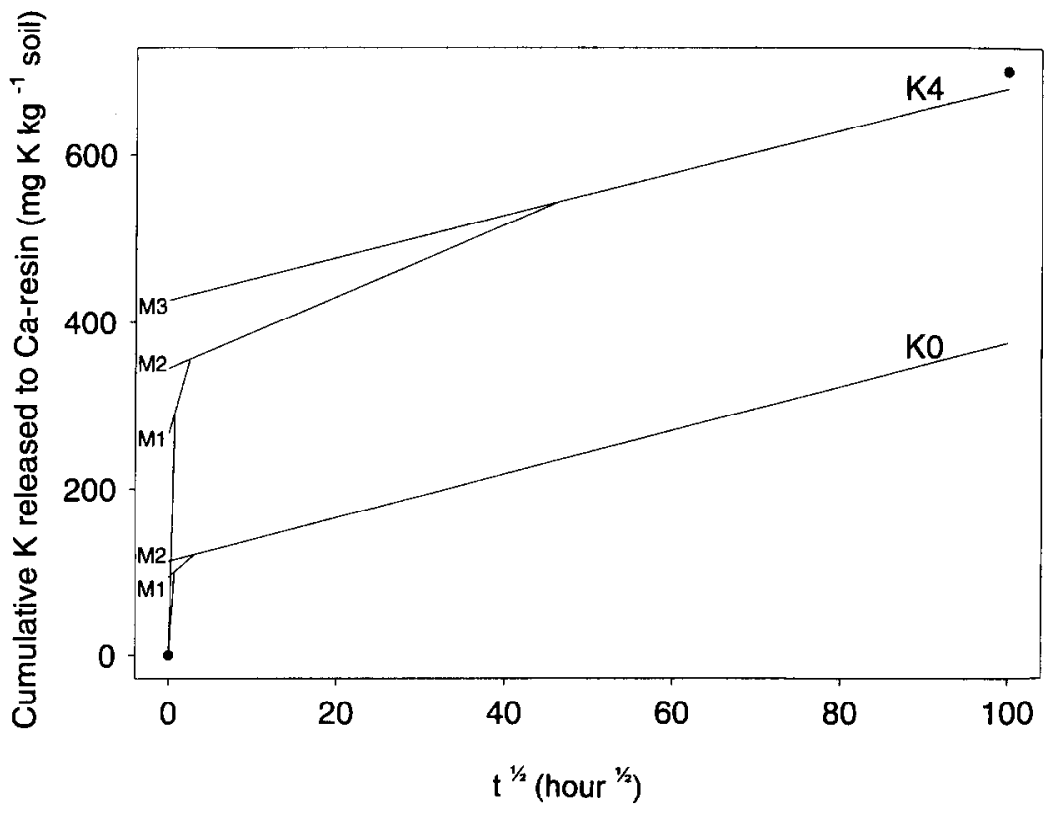

Fig. 1. Cumulative $\mathrm{K}$ release to $\mathrm{Ca}$-resin.

Table 1

Physico-chemical and mineralogical properties of the soil

\begin{tabular}{|c|c|c|c|c|c|c|c|c|c|c|c|c|}
\hline \multirow{2}{*}{$\begin{array}{l}\text { Depth } \\
\text { (cm) }\end{array}$} & \multirow[t]{2}{*}{ Clay } & \multirow{2}{*}{$\begin{array}{l}\text { Loam } \\
(\%)\end{array}$} & \multirow[t]{2}{*}{ Sand } & \multirow[t]{2}{*}{$\mathrm{pH}$} & \multirow{2}{*}{$\begin{array}{l}\text { O.M. } \\
(\%)\end{array}$} & \multirow{2}{*}{$\begin{array}{l}\text { C.E.C. } \\
\left(\mathrm{cmol} \mathrm{kg}{ }^{-1}\right)\end{array}$} & \multirow{2}{*}{$\begin{array}{l}\mathrm{CaCO}_{3} \\
(\%)\end{array}$} & \multirow{2}{*}{$\begin{array}{l}\text { Exchangeable } \\
\mathrm{K} \mathrm{mg} \mathrm{kg}^{-1} \text { soil }\end{array}$} & \multirow{2}{*}{$\begin{array}{l}\text { Total K } \\
(\%)\end{array}$} & \multicolumn{3}{|c|}{ Composition of the clay fraction (\%) } \\
\hline & & & & & & & & & & Illite & Smectite & Kaolinite \\
\hline $0-30$ & 31 & 42 & 27 & 8.3 & 1.8 & 18.5 & 5.6 & 190 & 2.53 & 40 & 35 & 10 \\
\hline $30-45$ & 30 & 43 & 27 & 8.4 & 1.3 & 16.3 & 6.4 & 118 & 2.5 & ND & ND & ND \\
\hline $45-60$ & 23 & 53 & 24 & 8.5 & 0.8 & 13.5 & 22.1 & 59 & 2.03 & ND & ND & ND \\
\hline $60-75$ & 14 & 54 & 32 & 8.4 & 0.5 & 12.5 & 24.5 & 42 & 1.92 & ND & ND & ND \\
\hline $75-90$ & 6 & 54 & 40 & 8.5 & 0.2 & 9.1 & 40.7 & 30 & 1.52 & ND & ND & ND \\
\hline
\end{tabular}

ND, not determined.

small increase ( $8 \mathrm{mg} \mathrm{K} \mathrm{kg}^{-1}$ soil). In contrast, plots receiving large amounts of fertilizers showed a large increase in their exchangeable $\mathrm{K}$ content (104 $\mathrm{mg} \mathrm{K} \mathrm{kg}^{-1}$ soil) which took place between 1979 and 1983; subsequently K concentration did not increase much. Average exchangeable $\mathrm{K}$ contents showed marked year-to-year variations, independently of treatments. For a given treatment, differences between two successive sampling dates were larger than differences between treatments for a given date.

\subsection{Potassium release kinetics}

Cumulative $\mathbf{K}$ released was plotted as a function of the square root of the cumulative reaction time for $\mathrm{K} 0$ and $\mathrm{K} 4$ soils (Fig. 1). The curves consist of several linear parts from which amounts $(M)$ and rates of release $(R)$ were calculated as described above.

Results show that $\mathrm{K}$ release kinetics clearly discriminate between the treatments from the beginning. The amount $M_{1}$ increased, as well as 


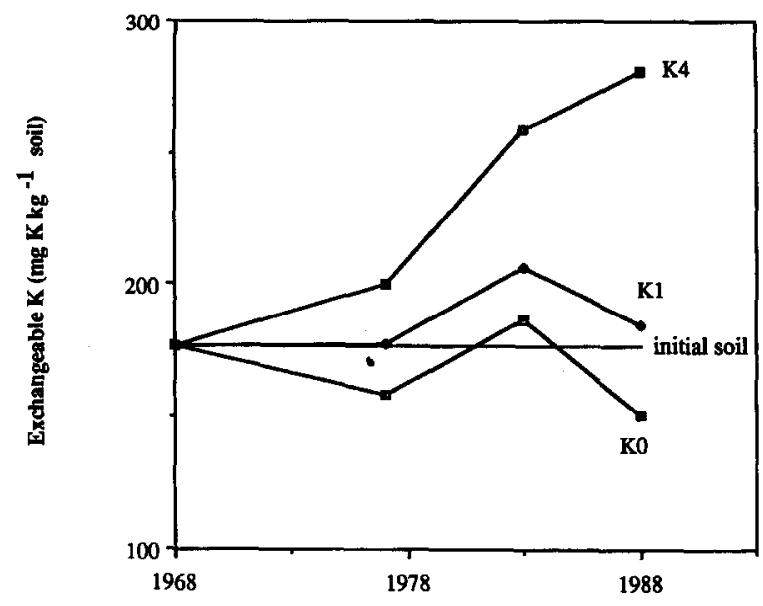

Fig. 2. Changes in $\mathrm{NH}_{4}$-acetate exchangeable $\mathrm{K}$ during 1968-1988.

the release rate coefficient $R_{1}$ (Fig. 1; Table 2): $94 \mathrm{mg} \mathrm{K} \mathrm{kg}^{-1}$ soil were released within $22 \mathrm{~min}$ from the $\mathrm{K} 0$ soil and $267 \mathrm{mg} \mathrm{K} \mathrm{kg}^{-1}$ soil within $25 \mathrm{~min}$ for the $\mathrm{K} 4$ soil. These amounts represent, respectively, 56 and $78 \%$ of total exchangeable $\mathrm{K}$ (Table 2). When cumulative extraction time exceeded $1900 \mathrm{~h}$ (80 days), no significant differences between treatments were noticeable; the linear segments were parallel and release rate coefficients similar: $2.6 \pm 0.1 \mathrm{mg} \mathrm{K} \mathrm{kg}^{-1}$ soil h $\mathrm{h}^{-1 / 2}$ for the $\mathrm{K} 0$ soil and $2.5 \pm 0.4 \mathrm{mg} \mathrm{K} \mathrm{kg}^{-1}$ soil h$^{-1 / 2}$ for the K4 one. Total amounts extracted after $6700 \mathrm{~h}$ matched the values obtained with NaTPB extraction and represented less than $5 \%$ of total soil $\mathrm{K}$ content (Table 1).

\section{Discussion}

\subsection{Grain yield response}

The effect of withholding $\mathrm{K}$ fertilizer for 25 years had a limited effect on average grain yields, except when two crops succeed one another in the same year without extra fertilizer inputs (pea and catchmaize in 1987).

The significant effect of treatments on grain yields which was noticeable for the catch-maize crop originates from possible exhaustion of exchangeable $\mathrm{K}$ reserves by the previous pea crop. Although availability of $\mathrm{K}$ in crop residues was virtually equivalent to that of fertilizer (Quémener, 1986), there was not enough time between the pea harvest (26 June) and maize sowing ( 30 June) for residues to decompose and release $\mathrm{K}$ for the next crop.

At harvest, on adjacent experimental fields, we measured total $\mathbf{K}$ absorbed in grain and aboveground parts for the eight species tested, which were managed in the same manner (Fig. 3). Results show that large amounts of $\mathrm{K}$ (exceeding $100 \mathrm{~kg} \mathrm{~K} \mathrm{ha}^{-1}$ ) were taken up by all eight crops. In comparison with cereals, legumes took up less $\mathrm{K}$ and removed proportionally more. Largest amounts were found for rape and sunflower, which removed over $200 \mathrm{~kg} \mathrm{~K} \mathrm{ha}^{-1}$; the part of the $\mathrm{K}$ taken off by the grain represented less than $10 \%$ of the total $\mathrm{K}$ taken up by above-ground parts for these two species.

Significant increases in total $\mathrm{K}$ content with treatment were observed for plants analysed at maximum absorption, but without yield increase.

Table 2

Amounts of $\mathrm{K}$ released to Ca-resin, release rate coefficients and $\mathrm{K}$ fertility status of $<2 \mathrm{~mm}$ soil fraction

\begin{tabular}{|c|c|c|c|c|c|c|c|c|c|c|}
\hline & \multicolumn{4}{|c|}{ Amount of $\mathrm{K}$ released (mg K kg ${ }^{-1}$ soil) } & \multicolumn{4}{|c|}{ Rate of $\mathrm{K}$ release $\left(\mathrm{mg} \mathrm{K} \mathrm{kg}^{-1}\right.$ soil h $\left.\mathrm{h}^{-1 / 2}\right)$} & \multicolumn{2}{|c|}{$\mathrm{K}$ fertility status (mg K kg ${ }^{-1}$ soil) } \\
\hline & $M_{1}^{\mathrm{a}}$ & $M_{2}$ & $M_{3}$ & $M_{\mathrm{t}}^{\mathrm{b}}$ & $R_{1}{ }^{\mathrm{c}}$ & $R_{2}$ & $R_{3}$ & $R_{4}$ & Exch. K & NaTPB K \\
\hline $\mathrm{K} 0$ & 94 & 19 & - & 315 & 156 & 8.6 & 2.6 & - & 167 & 328 \\
\hline K4 & 267 & 78 & 82 & 629 & 412 & 35 & 4.3 & 2.5 & 343 & 637 \\
\hline
\end{tabular}

${ }^{a} M_{1}, M_{2}, M_{3}$, amounts of $\mathrm{K}$ released, obtained from linear segments of the $\mathrm{K}$ release curve (see text).

${ }^{\mathrm{b}} M_{\mathrm{t}}$ Total amount released in $6700 \mathrm{~h}$.

${ }^{\mathrm{c}} R_{1}, R_{2}, R_{3}$, rates of $\mathrm{K}$ release, calculated as the slope of each segment $\left(M_{1}, M_{2}, M_{3}\right)$. 


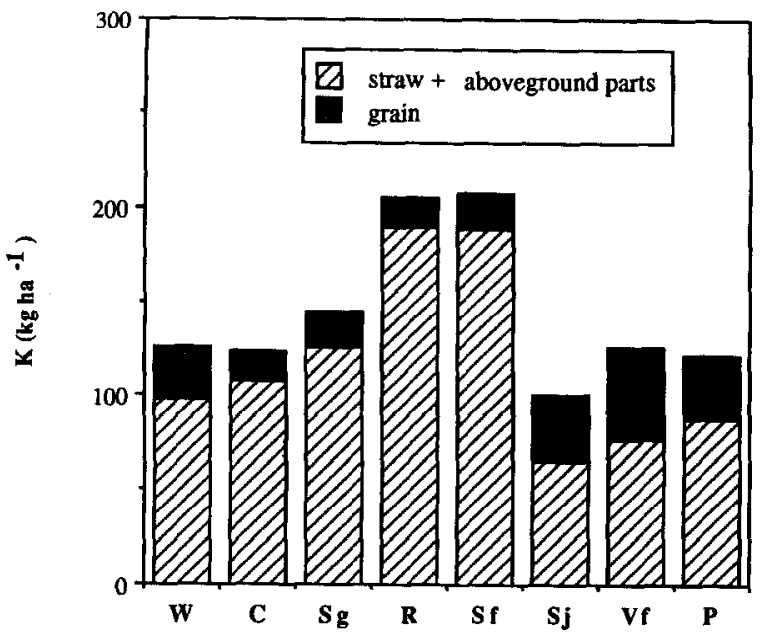

Fig. 3. K removed with grain and straw plus above-ground parts for the tested species. W, wheat; $M$, maize; $\mathrm{Sg}$, sorghum; R, rape; $\mathrm{Sf}$, sunflower; So, soyabean; $\mathrm{Vf}$, faba bean; $\mathrm{P}$, pea.

Havlin et al. (1984) and Parker et al. (1989) reported similar results with lucerne and maize respectively. Recently Barraclough and Leigh (1993) confirmed that for a given crop, $\mathrm{K}$ content at maximum mineral absorption (end of flowering) was the best indicator of the potential $\mathrm{K}$ supply from soils.

\subsection{Changes in soil K fertility status}

Exchangeable $\mathrm{K}$ contents on plots receiving no $\mathrm{K}$ declined slightly over the experimental period at a rate of $1.3 \mathrm{mg} \mathrm{K} \mathrm{kg}^{-1}$ soil year ${ }^{-1}$ (Fig. 2); these plots exhibited negative $\mathrm{K}$ balances: $-\mathbf{3 1} \mathrm{kg}$ $\mathrm{K} \mathrm{ha}^{-1}$ year $^{-1}$. Plots which received large amounts of $K$ (K4) showed maximum rates of increase: $5.2 \mathrm{mg} \mathrm{K} \mathrm{kg}^{-1}$ soil year ${ }^{-1}$; and their $\mathrm{K}$ balance was positive and equal to $108 \mathrm{~kg} \mathrm{~K} \mathrm{ha}^{-1}$ year $^{-1}$. Plots where $\mathrm{K}$ dressings were equal to offtakes (K1) exhibit a small increase of $\mathrm{K}$ of $0.4 \mathrm{mg}$ $\mathrm{K} \mathrm{kg}^{-1}$ soil year ${ }^{-1}$, the average $\mathrm{K}$ balance being $2 \mathrm{~kg} \mathrm{~K} \mathrm{ha}^{-1}$ year $^{-1}$. This result demonstrates that for these experimental conditions annual application of $33 \mathrm{~kg} \mathrm{~K}$ was adequate to maintain soil $\mathrm{K}$ concentration at its initial value, apart from the annual fluctuations which are not fully explained.

A close relationship existed at every sampling date between average nutrient balance (inputs- outputs) and exchangeable $\mathrm{K}$ balance, calculated for each treatment. From the relationship determined in 1988 (Fig. 4) we calculated that $164 \mathrm{~kg}$ of $\mathrm{K}$ are necessary to increase exchangeable $\mathrm{K}$ content by $10 \mathrm{mg} \mathrm{kg}^{-1}$ soil.

The exchangeable $\mathrm{K}$ balance calculated over the entire experimental period matched the $\mathrm{K}$ nutrient balance poorly. It remained far lower for plots with positive values $\left(468 \mathrm{~kg} \mathrm{~K} \mathrm{ha}^{-1}\right.$ compared to $2117 \mathrm{~kg} \mathrm{~K} \mathrm{ha}^{-1}$ ) and higher for those with negative ones $\left(-171 \mathrm{~kg} \mathrm{~K} \mathrm{ha}{ }^{-1}\right.$ compared to $-610 \mathrm{~kg}$ $\mathrm{K} \mathrm{ha}^{-1}$ ). These large discrepancies originated from the high buffer power for $\mathrm{K}$, which derives from the clay mineralogical fractions which control $\mathrm{K}$ release (illitic fraction) and fixation (smectitic fraction) (Robert et al., 1988); accordingly, this soil was able to release large amounts of non-exchangeable K. Similar behaviour observed for Colorado calcareous soils was related to high illite content (Havlin et al., 1984). On non-fertilized plots we may also expect $\mathrm{K}$ translocation from the subsoil by root action, which tends to increase the $K$ content of surface horizons through residue decomposition (McCallister et al., 1987).

These changes described above relate to the whole experimentation period; however, results show that the process was not taking place continu-

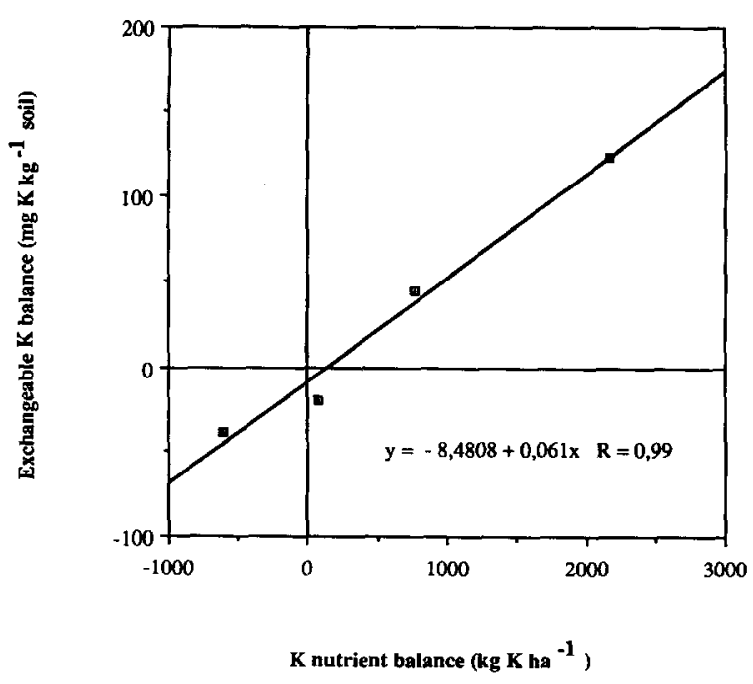

Fig. 4. Relationship between $\mathrm{K}$ nutrient balance (inputs-outputs) and exchangeable K balance (1968-1988). Points correspond to the four treatments (see text). 
ously: there were large discontinuities between two successive sampling dates. There are two possible explanations for this behaviour (Quémener, 1986):

(1) Exchangeable $\mathrm{K}$ determination is influenced by water content at sampling and drying; the alternation of wetting and drying cycles favours fixation or release according to whether the soil was fertilized or not before sampling (Quémener, 1986).

(2) The average amount of $\mathrm{K}$ returned to the field by residues at harvest represented between 65 and $190 \mathrm{~kg} \mathrm{~K} \mathrm{ha}^{-1}$ (Fig. 3). Following the 1983 harvest, rape residues returned large quantities of $\mathrm{K}$ to the soil, which amounted to a very generous fertilizer dressing. This could explain the subsequent steep increase in exchangeable $\mathrm{K}$ content in the $\mathrm{K} 0$ and $\mathrm{K} 1$ plots.

\subsection{Effect of fertilization on $K$ release kinetics}

Separation of release curves clearly discriminates between treatments (Fig. 1). Three segments are sufficient to explain $\mathrm{K}$ release kinetics data for $\mathrm{K} 0$ soil, whereas four are required for $\mathrm{K} 4$ soil. Fertilizer inputs markedly affected surface K, which represents the exchangeable fraction. It increased the amount as well as the rate of release for $\mathrm{K} 4$ soil in comparison with $\mathrm{K} 0$ treatments. For the last linear segment of the curve, both soils behaved similarly. Goulding and Loveland (1986) ascribed release rate coefficients of similar intensity measured on British soils to micas; the slowest $\mathrm{K}$ release was diffusion-controlled and originated from the clay matrix. Additional segments obtained for $\mathrm{K} 4$ soils represent $\mathrm{K}$ fertilizer residues fixed on the periphery of mica minerals (Goulding and Loveland, 1986); this fraction was not present in $\mathrm{K} 0$ soils.

Calcium resin is able to release non-exchangeable $\mathrm{K}$ from highly fertilized soil as well as from that without $\mathrm{K}$ applications for long periods (Table 2). The $\mathrm{K}$ exhaustion level reached for $\mathrm{K} 0$ treatments did not modify the capacity of the soil to release non-exchangeable $\mathrm{K}$ located within the clay matrix. Following 20 years without $\mathrm{K}$ applica- tion, this fraction was still able to provide crops with an adequate $K$ supply.

No matter what the $\mathrm{K}$ balance is in the field, this soil displayed a high $\mathrm{K}$ buffering capacity which meets the $\mathrm{K}$ requirements of crops, whether low or moderate.

\section{Conclusions}

Within the cropping system and for the different species tested, we were not able to reveal a significant decrease in yields on plots which had received no $\mathrm{K}$ fertilizer for 25 years.

The $\mathrm{K}$ buffering capacity of these soils was adequate to meet plant demand; the non-exchangeable $\mathrm{K}$ fraction was capable of providing additional $\mathrm{K}$. Moreover, the large amounts of $\mathrm{K}$ returned to the soil through residues corresponded in quantity and quality to large annual dressings. Potassium is not a factor limiting grain production in this cropping system, established on a calcareous soil without very demanding crops. As a consequence, withholding $\mathrm{K}$ fertilizer for several years involves little risk of yield loss under these circumstances (Havlin et al., 1984; Withers et al., 1994).

Exchangeable $\mathrm{K}$ content does not express the changes with time in nutrient balance in a satisfactory way: the marked annual fluctuations are difficult to explain. Analysis of soil fertility shows that withholding $\mathrm{K}$ slightly decreases $\mathrm{K}$ content. We may ask how soil $\mathrm{K}$ fertility will be maintained if the crop rotation includes industrial crops or fallow; in such a situation $\mathrm{K}$ balance (inputsoutputs) will be modified in a very significant manner since crop residues will be totally removed or very limited; as a result soil $\mathrm{K}$ fertility will be affected more severely. These factors will have to be taken into consideration when managing the sustainability of highly diversified cultural systems.

So far, the methodology carried out does not reveal a clear differentiation of $\mathbf{K}$ fractions after 20 years of experimentation. Potassium release kinetics evaluated through sequential $\mathrm{Ca}$-resin extraction show that only "surface" and "periphery" K as defined by Talibudeen et al. (1978) are differentiated by fertilization regimes. Long-term K supply capacities are not modified by the treat- 
ments; $\mathrm{K} 0$ and $\mathrm{K} 4$ soils had similar release rate coefficients for slow $\mathrm{K}$ release from the clay matrix. These results emphasize the role of the mineralogical clay fraction which has a high $\mathrm{K}$ buffer power and controls most of the fixation and release processes taking place in soils.

\section{Acknowledgment}

This work was supported by I.N.R.A.-A.I.P. no. 91/4755 "Etude de la mobilité des éléments dans le sol". We express our gratitude to A. Hilaire who provided the $\mathrm{K}$ content data reported in Fig. 3, to A. Schneider who performed the NaTPB extractions and to Dr. A. Scaife for his help in the correction of the English draft.

\section{References}

Badraoui, M., Bloom, P.R. and Delmaki, A., 1992. Mobilization of non-exchangeable $\mathrm{K}$ by ryegrass in five Moroccan soils with and without mica. Plant Soil, 140: 55-63.

Barraclough, P.B. and Leigh, R.A., 1993. Critical plant concentrations for growth and problems in the diagnosis of nutrient deficiencies by plant analysis. Plant Soil, 155: 219-222.

Bosc, M., 1988. Enseignements fournis par des essais de longue durée sur la fumure potassique et phosphatée 3- Essais sur la fumure potassique. In: L. Gachon (Editor), Phosphore et Potassium dans les relations sol-plante: conséquences sur la fertilisation. 1.N.R.A., Paris, pp. 403-466.

Fardeau, J.C., Poss, R. and Sarangoni, H., 1992. Effect of potassium fertilization on K-cycling in different agrosystems. In: J. Petr (Editor), Potassium in Ecosystems. I.P.I., Basel, pp. $59-78$.

Goulding, K.W.T. and Loveland, P.J., 1986. The classitication and mapping of potassium reserves in soils of England and Wales. J. Soil Sci., 37: 555-565.

Goulding, K.W.T., 1984. The availability of potassium in soils to crops as measured hy its release to a calcium-saturated cation exchange resin. J. Agric. Sci. Cambridge, 103: 265-275.

Havlin, J.L., Westfall, D.G. and Golus, H.M., 1984. Six years of phosphorus and potassium fertilization of irrigated alfalfa on calcareous soils. Soil Sci. Soc. Am. J., 48: 331-336.

Havlin, J.L., Westfall, D.G. and Olsen, S.R., 1985. Mathematical models for potassium release kinetics in calcareous soils. Soil Sci. Soc. Am. J., 49: 371-376.

Jackson, M.L., 1969. Soil chemical analysis. Advanced course 2nd Edition, 11th printing. Published by the author, Madison, $895 \mathrm{pp}$.

McCallister, D.L., Shapiro, C.A., Raun, W.R., Anderson, F.N., Remh, G.W., Engelstad, O.P., Russelle, M.P. and Olson, R.A., 1987. Rate of phosphorus and potassium buildup/decline with fertilization for corn and wheat on Nebraska mollisols. Soil Sci. Soc. Am. J., 51: 1646-1652.

Mengel, K. and Uhlenbecker, K., 1993. Determination of available interlayer potassium and its uptake by ryegrass. Soil Sci. Soc. Am. J., 57: 761-766.

Metson, A.J., 1956. Methods of chemical analysis for soil survey samples. New Zealand Soil Bureau Bull., no. 12.

Parker, D.R., Sparks, D.L., Hendricks, G.J. and Sadusky, M.C., 1989. Potassium in atlantic coastal plain soils. II. Soil characterization and distribution of potassium. Soil Sci. Soc. Am. J., 53: 392-396.

Quémener, J., 1986. Important factors in potassium balance sheets. In: H. Laudelout (Editor), Nutrient Balances and the Need for Polassium. I.P.I., Bern, pp. 41-72.

Reed, M.G. and Scott, A.D., 1962. Kinetics of potassium release from biotite and muscovite in sodium tetraphenylboron solution. Soil Sci. Soc. Am. Proc., 26: 437-440.

Robert, M., Guyot, J. and Hervio, M., 1988. Minéralogie des sols et dynamique du potassium. In: L. Gachon (Editor), Phosphore et Potassium dans les relations sol-plante: conséquences sur la fertilisation. I.N.R.A., Paris, pp. 13-31.

Talibudeen, O., Beasley, J.D., Lane, P. and Rajendran, N., 1978. Assessment of soil potassium reserves available to plant roots. J. Soil Sci., 29: 207-218.

Withers, P.J.A., Unwin, R.J., Grylls, J.P. and Kane, R., 1994. Effects of withholding phosphate and potash fertilizer on grain yield of cereals and on plant-available phosphorus and potassium in calcareous soils. Eur. J. Agron. 3: 1-8. 